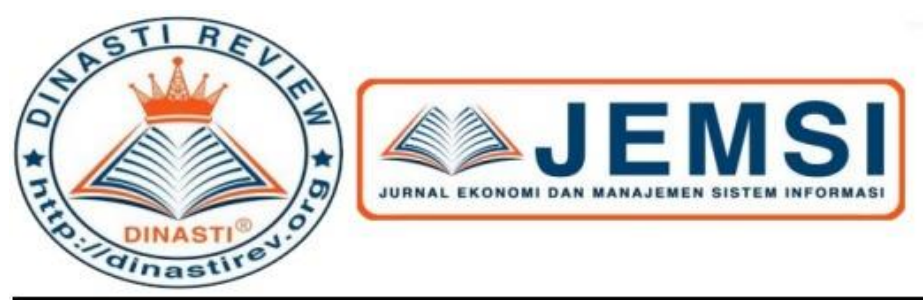

+62 878-9658-6407

087896586407 (Q)

https://dinastirev.org/JEMSI (-)

editor@dinastirev.org (6.)

\title{
PENGARUH MODERNISASI SISTEM ADMINISTRASI PERPAJAKAN, SANKSI PAJAK TERHADAP KEPATUHAN WAJIB PAJAK ORANG PRIBADI PADA KPP PRATAMA
}

\author{
Faiz Alvin Barra Fathani ${ }^{1)}$ Apollo ${ }^{2)}$ \\ 1) Jurusan Akuntansi, Fakultas Ekonomi dan Bisnis, Universitas Mercu Buana \\ 2) Jurusan Akuntansi, Fakultas Ekonomi dan Bisnis, Universitas Mercu Buana
}

\begin{tabular}{|c|l|}
\hline $\begin{array}{c}\text { ARTICLE INFORMATION } \\
\text { Received: 5 Februari 2020 } \\
\text { Revised: 10 Februari 2020 }\end{array}$ & $\begin{array}{l}\text { Abstrak: Penelitian ini bertujuan untuk menguji } \\
\text { pengaruh modernisasi sistem administrasi } \\
\text { perpajakan, sanksi perpajakan terhadap kepatuhan }\end{array}$ \\
Issued: 16 Februari 2020 & $\begin{array}{l}\text { wajib pajak orang pribadi yang terdaftar di Kantor } \\
\text { Pelayanan Pajak (KPP) Pramata Jakarta - Palmerah. } \\
\text { Penelitian Ini termasuk ke dalam jenis penelitian } \\
\text { Faiz Alvin Barra Fathani } \\
\text { E-mail: }\end{array}$ \\
kausal. Populasi dalam penelitian ini adalah wajib \\
pajak orang pribadi yang terdaftar di Kantor \\
Pelayanan Pajak Pratama Jakarta -Palmerah, \\
dengan pengumpulan data mengguanakan metode \\
langsung dengan menyebarkan kuesioner kepada \\
wajib pajak. Teknik pengambilan sempel \\
menggunakan simple random sampling. Teknik \\
analisis data yang digunakan dalam penelitian ini \\
adalah Analisis Partial Least Square (PLS) dengan \\
menggunakan software Smart-PLS 3.0. Berdasarkan \\
hasil analisis data diambil kesimpulan bahwa \\
pertama, terdapat pengaruh signifikan dan positif \\
Modernisasi Sistem Administrasi Perpajakan \\
terhadap kepatuhan wajib pajak. Kedua, terdapat \\
pengaruh signifikan dan positif Sanksi pajak \\
terhadap kepatuhan wajib pajak. \\
Kata Kunci: Modernisasi Sistem Administrasi \\
Perpajakan, Sanksi Perpajakan, Kepatuhan Wajib \\
Pajak
\end{tabular}

\section{PENDAHULUAN}

Dalam struktur penerimaan Negara, perpajakan merupakan bentuk komponen yang terbesar dalam negeri untuk membantu pembiayaan operasional pemerintahan dan pembangunan Negara. Selain mampu menyediakan sumber dana bagi pembiayaan berbagai proyek penanggulangan dampak krisis ekonomi, penerimaan perpajakan juga dapat mencegah terjadinya pembengkakan defisit anggaran. Pajak tidak hanya dinikmati oleh pembayar pajak saja tapi untuk menunjang kepentingan negara untuk tercapainya kesejahteraan di Indonesia. Pemerintah sangat menyadari bahwa pendapatan negara dari sektor pajak sangatlah penting, sehingga pemerintah setiap tahunnya selalu berusaha untuk meningkatkan penerimaan pajak. 
Pemerintah Indonesia akan terus berusaha meningkatkan sumber penerimaan dalam negeri khususnya di sektor pajak sebagai wujud pelaksanaan pembangunan nasional.

Keberhasilan penerimaan pajak suatu negara tergantung kepada upaya pemerintahnya dalam meningkatkan kepatuhan wajib pajak dan menekan tindakan manipulasi pajak. Beberapa langkah yang dapat dilakukan pemerintah antara lain menciptakan pelayanan publik yang profesional, mengelola uang pajak secara adil dan transparan, membuat peraturan perpajakan yang mudah dipahami wajib pajak dan meningkatkan tindakan penegakan hukum (law enforcement) kepada wajib pajak yang tidak patuh.(www.pajak.go.id) Kepatuhan Wajib Pajak dapat diukur dari pemahaman terhadap semua ketentuan peraturan perundang-undangan perpajakan, mengisi formulir dengan lengkap dan jelas, menghitung jumlah pajak yang terutang dengan benar,membayar dan melaporkan pajak yang terutang tepat pada waktunya. (Adiasa, 2013).

Penelitian ini terdiri dari pendahuluan tentang masalah yang dibahas didalamnya, kemudian dilanjutkan dengan teori dan penelitian sebelumnya tentang faktor-faktor yang mempengaruhi kepatuhan wajib pajak yaitu modernisasi sistem administrasi perpajakan, kesadaran perpajakan, sanksi pajak, dan pelayanan fiskus. Selanjutnya dibahas mengenai model penelitian yang ditawarkan dalam makalah ini, dan kemudian penutup yang berisi rekomendasi yang diberikan untuk peneliti yang ingin melakukan penelitian tentang faktor-faktor yang mempengaruhi kepatuhan wajib pajak orang pribadi.

Tabel 1. Tingkat Kepatuhan Penyampaian SPT

\begin{tabular}{|l|l|l|l|}
\hline Tahun & JumlahWajibPajak & Jumlah WP Lapor & RasioKepatuhan \\
\hline 2016 & 16,5 juta & 9,7 juta & $58,97 \%$ \\
\hline 2017 & 17,6 juta & 10,58 juta & $59,98 \%$ \\
\hline 2018 & 17,6 juta & 12,5 juta & $71 \%$ \\
\hline 2019 & 18,3 juta & 12,3 juta & $67,2 \%$ \\
\hline
\end{tabular}

Sumber: www.pajak.go.id

Dari data yang telah di paparkan, terlihat bahwa jumlah Wajib Pajak yang melaporkan SPT di tahun 2016 sampai 2019 meningkat meskipun tidak lebih dari 75\% Wajib Pajak yang melaporkan SPTnya, sedangkan di tahun 2019 tingkat kepatuhan Wajib Pajak menurun menjadi kurang dari 70\% atau sekitar 12,3 juta Wajib Pajak yang melaporkan SPTnya dari 18,3 juta Wajib Pajak yang terdaftar di sistem Direktorat Jendral Pajak (DJP). Hal ini disebabkan karena masih rendahnya kesadaran Wajib Pajak dalam menyampaikan SPT dan hal ini membuktikan bahwa tingkat kepatuhan Wajib Pajak masih sangat rendah yang menyebabkan tingkat penerimaan Negara dari sektor pajak tidak mencapai target.

\section{KAJIAN PUSTAKA}

\section{Teori Perilaku Berencana (Theory Of Planned Behavior)}

Perilaku diterjemahkan dari bahasa Inggris, behavior dan ditafsirkan secara berbeda oleh para pakar, Menurut Kamus Besar Bahasa Indonesia, perilaku adalah tanggapan atau reaksi individu terhadap rangsangan atau lingkungan (KBBI-online). Dalam wikipedia disebutkan bahwa perlilaku adalah sekumpulan perilaku yang dimiliki oleh manusia dan dipengaruhi adat, sikap, emosi, nilai, etika, kekuasaan persuasi, dan genetika. Menurut Robert Kwik (1974) dalam Wardiah (2016:13) Perilaku dipandang dari segi biologi adalah kegiatan atau aktivitas organisme yang dapat diamati bahkan dipelajari.

\section{Teori Kepatuhan (Compliace Theory)}


Menurut Tyler (Saleh, 2004)

Terdapat dua perspektif dalam literatur sosiologi mengenai kepatuhan kepada hukum, yang disebut instrumental dan normatif.

1. Perspektif instrumental mengasumsikan individu secara utuh didorong oleh kepentingan pribadi dan tanggapan terhadap perubahan-perubahan yang berhubungan dengan perilaku.

2. Perspektif normatif berhubungan dengan apa yang orang anggap sebagai moral dan berlawanan dengan kepentingan pribadi.

\section{METODE PENELITIAN}

Jenis penelitian ini adalah causal karena penelitian ditujukan untuk mengetahui pengaruh antara satu atau lebih variabel bebas (independent varialel) terhadap variabel terikat (Y), dan bagaimana tanggapan responden mengenai Modernisasi Sistem Administrasi Perpajakan sebagai $\left(\mathrm{X}_{1}\right)$, Sanksi Perpajakan sebagai $\left(\mathrm{X}_{2}\right)$. Studi empiris dilakukan pada wajib pajak orang pribadi di Kantor Pelayanan Pajak Pratama Jakarta Palmerah.

\section{HASIL DAN PEMBAHASAN}

Kuesioner yang disebar memperoleh responden sebanyak 100 wajib pajak orang pribadi yang telah diuji kelayakannya untuk dijadikan sampel dalam penelitian ini.

\section{Hasil Uji Statistik Deskriptif}

Statistik deskriptif digunakan untuk menggambarkan karateristik variabel yang diteliti yaitu, Modernisasi Administrasi Perpajakan $\left(\mathrm{X}_{1}\right)$ Sanksi Perpajakan $\left(\mathrm{X}_{2}\right)$, dan Kepatuhan Wajib Pajak (Y).

Tabel 2. HASIL UJI DESKRIPTIF

Hasil Analisis Statistik Deskriptif Modernisasi Administrasi Perpajakan ( $\left.\mathbf{X}_{1}\right)$

\begin{tabular}{|c|c|c|c|c|c|}
\hline & Mean & Median & Min & Max & $\begin{array}{c}\text { Standard } \\
\text { Deviation }\end{array}$ \\
\hline M1 & 3.960 & 4.000 & 1.000 & 5.000 & 0.848 \\
\hline M2 & 4.220 & 4.000 & 3.000 & 5.000 & 0.610 \\
\hline M3 & 4.310 & 4.000 & 2.000 & 5.000 & 0.703 \\
\hline M4 & 4.060 & 4.000 & 2.000 & 5.000 & 0.892 \\
\hline M5 & 3.970 & 4.000 & 2.000 & 5.000 & 1.023 \\
\hline M6 & 4.170 & 4.000 & 2.000 & 5.000 & 0.749 \\
\hline M7 & 3.370 & 4.000 & 1.000 & 5.000 & 1.130 \\
\hline
\end{tabular}

Sumber : Diolah Oleh Peneliti 2020

Variabel Modernisasi Administrasi Perpajakan dikukur dengan mengunakan 7 item pernyataan sesuai dengan indikator. Berdasarkan gambar di atas dapat diketahui bahwa jawaban responden atas pernyataan yang berkaitan dengan Sistem Administrasi Perpajakan tersebut menunjukan kisaran 1 sampai dengan 5. Dengan nilai mean pada setiap indikator kisaran 3.370 sampai dengan 4.220, nilai median 4, dan standar devisiasi menunjukan kisaran 0.610 sampai dengan 1,130. Hal ini menunjukan bahwa responden memiliki penggunaan Sistem Administrasi Perpajakan yang baik. 
Tabel 3. Hasil Analisis Statistik Deskriptif Sanksi pajak $\left(\mathbf{X}_{2}\right)$

\begin{tabular}{|c|c|c|c|c|c|}
\hline & Mean & Median & Min & Max & $\begin{array}{c}\text { Standard } \\
\text { Deviation }\end{array}$ \\
\hline S1 & 4.200 & 4.000 & 2.000 & 5.000 & 0.837 \\
\hline S2 & 3.930 & 4.000 & 1.000 & 5.000 & 0.962 \\
\hline S3 & 4.280 & 4.000 & 1.000 & 5.000 & 0.763 \\
\hline S4 & 3.990 & 4.000 & 1.000 & 5.000 & 0.985 \\
\hline S5 & 4.170 & 4.000 & 1.000 & 5.000 & 0.788 \\
\hline S6 & 4.270 & 4.000 & 2.000 & 5.000 & 0.646 \\
\hline S7 & 4.220 & 4.000 & 1.000 & 5.000 & 0.965 \\
\hline
\end{tabular}

Sumber : Diolah Oleh Peneliti 2020

Berdasarkan gambar di atas jawaban responden pada masing-masing variabel, terlihat memberikan informasi sebagai berikut, variabel Sanksi Perpajakan diukur mengunakan 7 item pernyataan sesuai indikator. Berdasarkan gambar di atas dapat diketahui bahwa jawaban responden atas pernyataan yang berkaitan dengan Sanksi Perpajakan tersebut menunjukan kisaran 1 sampai dengan 5 dengan nilai mean pada setiap indikator kisaran 3.930 sampai dengan 4.280, nilai median 4, dan standar devisiasi menunjukan kisaran 0.646 sampai dengan 0.985. Hal Ini menunjukan bahwa responden memiliki pengetahuan tentang sanksi perpajakan yang cukup baik.

Tabel 4. Hasil Analisis Statistik Deskriptif Kepatuhan Wajib Pajak (Y)

\begin{tabular}{|c|c|c|c|c|c|}
\hline & Mean & Median & Min & Max & $\begin{array}{c}\text { Standard } \\
\text { Deviation }\end{array}$ \\
\hline K1 & 3.780 & 4.000 & 1.000 & 5.000 & 1.171 \\
\hline K2 & 3.830 & 4.000 & 1.000 & 5.000 & 0.813 \\
\hline K3 & 3.830 & 4.000 & 1.000 & 5.000 & 0.895 \\
\hline K4 & 3.750 & 4.000 & 2.000 & 5.000 & 0.942 \\
\hline K5 & 4.130 & 4.000 & 2.000 & 5.000 & 0.730 \\
\hline K6 & 4.020 & 4.000 & 1.000 & 5.000 & 0.812 \\
\hline K7 & 3.660 & 4000 & 2.000 & 5.000 & 0.951 \\
\hline
\end{tabular}

Sumber : Diolah Oleh Peneliti 2020

Variabel Kepatuhan Pajak dikukur dengan mengunakan 4 item pernyataan sesuai dengan indikator. Berdasarkan gambar di atas dapat diketahui bahwa jawaban responden atas pernyataan yang berkaitan dengan Sistem Administrasi Perpajakan tersebut menunjukan kisaran 1 sampai dengan 5. mean pada setiap indikator kisaran 3.660 sampai dengan 4.130, nilai median 4, dan standar devisiasi menunjukan kisaran 0.730 sampai dengan 1.171 . Hal ini menunjukan bahwa responden di Kantor Pelayanan Pajak (KPP) Pratama Jakarta - Palmerah memiliki kepatuhan yang baik.

\section{UJI VALIDITAS}

\section{Convergent Validity}



berikut:

Adapun ringkasan dari uji validitas dari tiga variabel tersebut pada tabel 2 sebagai

Tabel 5. Hasil Pengujian Convergent Validity

\begin{tabular}{|c|c|c|c|}
\hline Variabel & Indikator & $\begin{array}{c}\text { Outer } \\
\text { Loadings }\end{array}$ & Keterangan \\
\hline \multirow{4}{*}{$\begin{array}{l}\text { Moderenisasi } \\
\text { Sistem } \\
\text { Administrasi } \\
\text { Perpajakan }\left(\mathrm{X}_{1}\right)\end{array}$} & $\begin{array}{l}\text { 1. Pelaporan pajak melalui e-SPT } \\
\text { dan } e \text {-Filling sangat efektif }\end{array}$ & 0.785 & VALID \\
\hline & $\begin{array}{l}\text { 2. Petugas pajak rutin melakukan } \\
\text { pemeriksaan pajak }\end{array}$ & 0.625 & VALID \\
\hline & $\begin{array}{l}\text { 3. Petugas pajak rutin melakukan } \\
\text { penyuluhan } \\
\text { pajak. }\end{array}$ & 0.839 & VALID \\
\hline & $\begin{array}{l}\text { 4. Petugas pajak selalu siap } \\
\text { membantu }\end{array}$ & 0.896 & VALID \\
\hline \multirow[t]{4}{*}{ Sanksi Pajak $\left(\mathrm{X}_{2}\right)$} & $\begin{array}{l}\text { 1. Sanksi pajak diberlakukan } \\
\text { dengan tegas kepada setiap } \\
\text { wajib pajak yang melanggar } \\
\text { ketentuan perpajakan }\end{array}$ & 0.715 & VALID \\
\hline & $\begin{array}{l}\text { 2. Penerapan sanksi pajak harus } \\
\text { sesuai dengan undang-undang } \\
\text { pajak }\end{array}$ & 0.790 & VALID \\
\hline & $\begin{array}{l}\text { 3. Adanya sosialisasi perubahan } \\
\text { sanksi pajak pada undang- } \\
\text { undang pajak kepada } \\
\text { Masyarakat }\end{array}$ & 0.684 & VALID \\
\hline & $\begin{array}{l}\text { 4. Sanksi perpajakan yang lebih } \\
\text { berat untuk memberikan efek } \\
\text { jera }\end{array}$ & 0.791 & VALID \\
\hline \multirow[t]{7}{*}{$\begin{array}{l}\text { Kepatuhan Wajib } \\
\text { Pajak (Y) }\end{array}$} & $\begin{array}{l}\text { 1. Saya mendaftarkan NPWP atas } \\
\text { kemauan sendiri }\end{array}$ & 0.812 & VALID \\
\hline & $\begin{array}{l}\text { 2. Setiap wajib pajak harus } \\
\text { mendaftarkan diri untuk NPWP }\end{array}$ & 0.773 & VALID \\
\hline & $\begin{array}{l}\text { 3. Saya telah mengetahui batas } \\
\text { akhir dalam pelaporan pajak }\end{array}$ & 0.729 & VALID \\
\hline & $\begin{array}{l}\text { 4. Penerapan sanksi yang tegas } \\
\text { dapat mendorong wajib pajak } \\
\text { untuk jujur }\end{array}$ & 0.856 & VALID \\
\hline & $\begin{array}{l}\text { 5. Pemeriksaan pajak oleh petugas } \\
\text { pajak dapat mendorong wajib } \\
\text { pajak untuk berlaku jujur }\end{array}$ & 0.612 & VALID \\
\hline & $\begin{array}{l}\text { 6. Banyaknya tempat pembayaran } \\
\text { dapat mempermudah wajib } \\
\text { pajak untuk membayar tepat } \\
\text { waktu }\end{array}$ & 0.551 & VALID \\
\hline & $\begin{array}{l}\text { 7. Saya selalu tepat waktu dalam } \\
\text { membayar pajak }\end{array}$ & 0.591 & VALID \\
\hline
\end{tabular}

Sumber : Diolah Oleh Peneliti 2020

Dari tabel di atas dapat dilihat nilai loading factor untuk setiap indikator dari masing- 
masing variabel laten masih memiliki nilai loading factor yang tinggi. Dengan demikian, suatu indikator dinyatakan valid jika mempunyai loading factor tertinggi kepada konstruk yang dituju dibandingkan loading factor kepada konstruk lain.

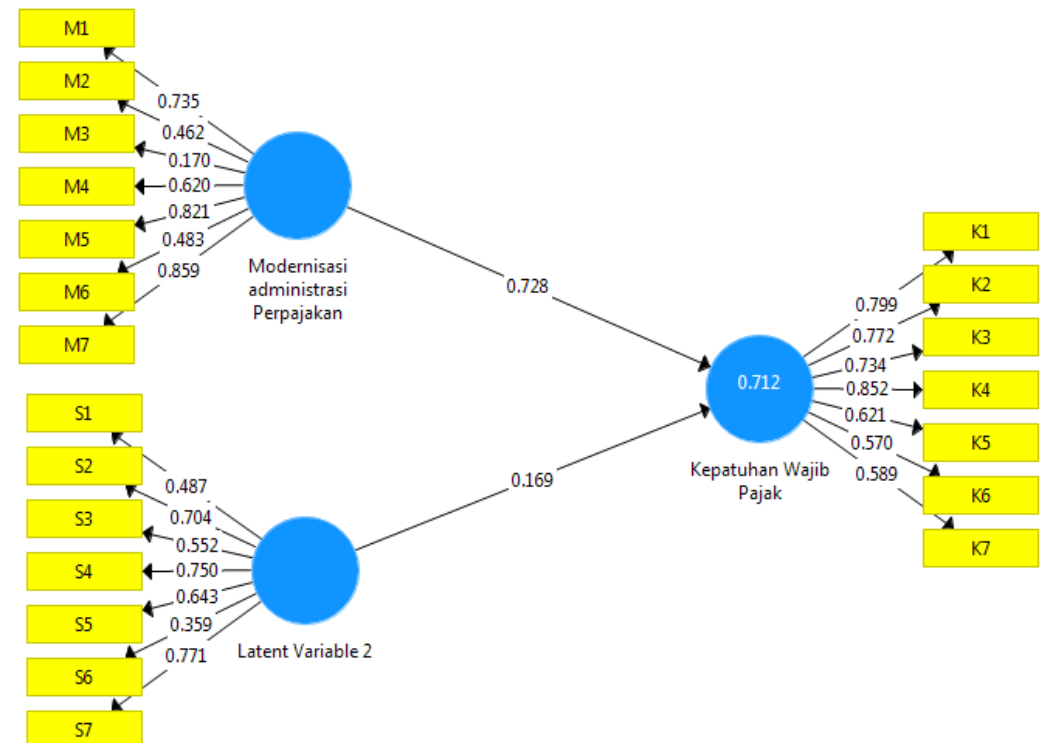

Gambar 1. Full Structural Model

Sumber : Output PLS, 2020

Hasil diatas dapat dilihat bahwa sebagian indikator tidak memenuhi convergent validity karena memiliki nilai loading factor dibawah 0,50.

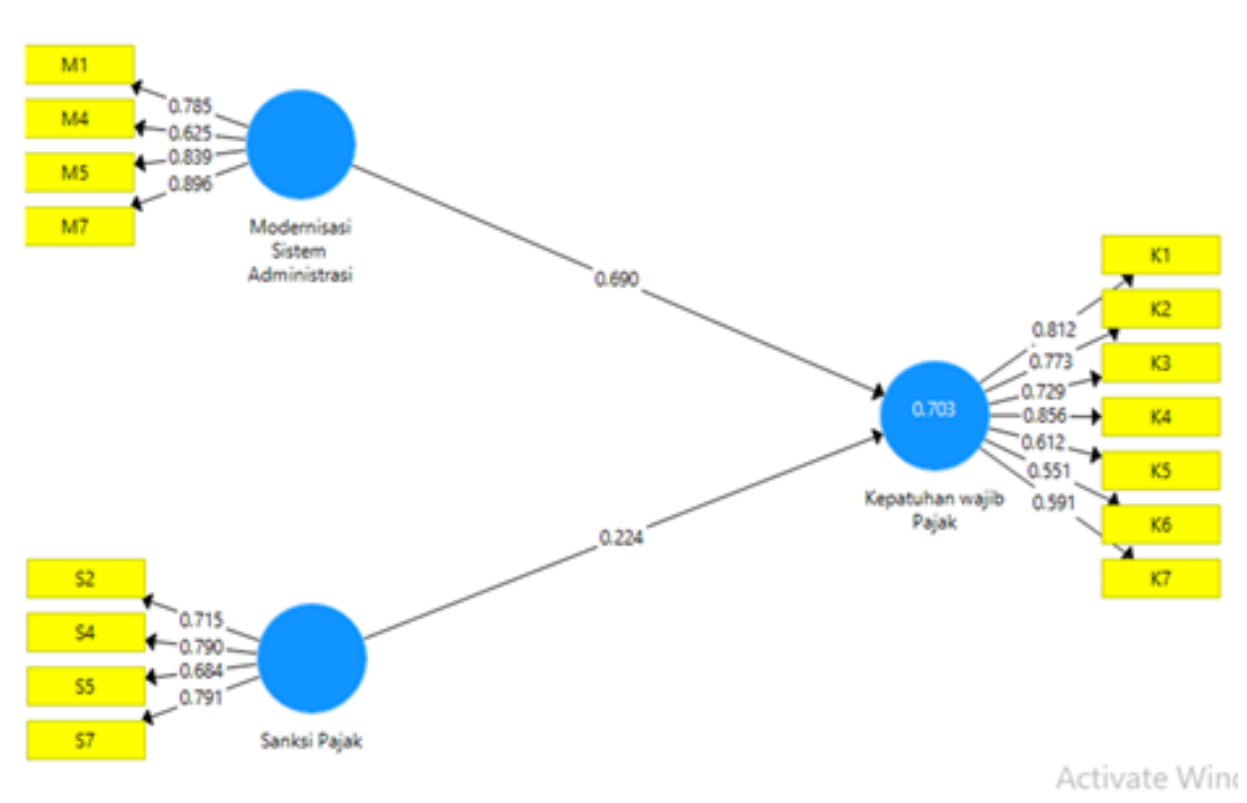

Gambar 2. Full Structural Model

Sumber : Output PLS, 2020

Hasil diatas dapat dilihat bahwa semua indikator telah memenuhi convergent validity karena memiliki nilai loading factor diatas 0,50 .

2. Pengujian Model struktual/Uji Hipotesis (Inner Model)

Pengujian inner model adalah pengembangan model berbasis konsep dan teori 
dalam rangka menganalisis hubungan antara variabel eksogen dan endogen telah dijabarkan dalam kerangka konseptual. Evaluasi model struktual atau inner model bertujuan untuk memprediksi hubungan antar variabel laten. Tahapan pengujian terhadap model strucktual inner model, dilakukan dengan langkah-langkah berikut ini:

1. Nilai R-Square

Melihat nilai R-Square yang merupakan uji goodness fit model.

Tabel 6. Nilai $\mathbf{R}^{2}$ Variabel Endogen

\begin{tabular}{|c|c|}
\hline Variabel & R Square \\
\hline Kepatuhan Wajib Pajak & 0.703 \\
\hline
\end{tabular}

Sumber : Diolah Oleh Peneliti 2020

Dari tabel di atas dapat disimpulkan bahwa nilai R-Square sebesar 0,703 yang berarti variabelitas kepatuhan pajak yang dapat dijelaskan oleh kedua variabel dalam model yaitu Modernisasi Sistem Administrasi Perpajakan, Sanksi Pajak sebesar 70,3\%.

\section{Hasil Pengujian Hipotesis (Estimasi Koefisien Jalur)}

Nilai estimasi untuk hubungan jalur model struktual harus signifikan. Nilai signifikasi ini dapat diperoleh dengan prosedur bootsreppng. Melihat signifikasi T-statistik pada algoritma boostrepping report nili T-statistik harus lebih dari 1,96. Selain itu juga dengan melihat $P$ value. Disebut signifikan apabila $\mathrm{P}$ values $\leq$ dari pada level (alpha) 0,05. Sebaliknya disebut tidak signifikan $P$ values $\geq$ dari level (alpha) 0,05.

Tabel 7.Hasil Pengujian Hipotesis

\begin{tabular}{|c|c|c|c|c|c|}
\hline Variabel & $\begin{array}{c}\text { Original } \\
\text { Sampel }\end{array}$ & $\begin{array}{c}\text { Sampel } \\
\text { Mean }\end{array}$ & $\begin{array}{c}\text { Standard } \\
\text { Deviation } \\
\text { (STDEV) }\end{array}$ & $\begin{array}{c}\text { T Statistic } \\
(\mid \text { O/STDV|) }\end{array}$ & $\begin{array}{c}\text { Palues } \\
\text { Moderenisasi } \\
\begin{array}{c}\text { Administrasi } \\
\text { Perpajakan >> } \\
\text { Kepatuhan Wajib } \\
\text { Pajak }\end{array}\end{array}$ \\
$\begin{array}{c}\text { Sajak } \\
\text { Sanksi Perpajakan } \\
\text { >> Kepatuhan } \\
\text { Wajib Pajak }\end{array}$ & 0.690 & 0.691 & 0.056 & 12.286 & 0.000 \\
\hline
\end{tabular}

Sumber : Diolah Oleh Peneliti 2020

Dari tabel diatas dijelaskan beberapa hal sebagai berikut:

a. Hasil pengujian hipotesis satu menunjukan hubungan variabel Modernisasi Sistem Administrasi perpajakan dengan kepatuhan wajib pajak menunjukan nilai koefisien jalur sebesar 0,690 degan nilai t sebesar 12,286. Nilai tersebut lebih besar dari nilai t tabel 1,96. Hasil ini berarti bahwa Kesadaran wajib Pajak memiliki hubungan yang berpengaruh positif dan signifikan terhadap kepatuhan wajib pajak. hal ini berarti Hipotesis 1 diterima.

b. Hasil pengujian hipotesis kedua menunjukan bahwa hubungan variabel Sanksi Perpajakan dengan Kepatuhan Wajib Pajak menunjukan nilai koefisien jalur sebesar 0,224 dengan nilai t sebesar 3,456. Nilai tersebut lebih besar dari t tabel 1,96. Hasil ini berarti Sanksi Perpajakan memiliki hubungan yang berpengaruh positif dan signifikan terhadap terhadap kepatuhan wajib pajak. hal ini berarti Hipotesis 2 diterima.

\section{Pembahasan Hasil Penelitian}




\section{Pengaruh implementasi sistem administrasi perpajakan terhadap kepatuhan wajib Pajak}

Implementasi Modernisasi Sistem Administrasi Perpajakan mempunyai pengaruh yang positif dan signifikan terhadap kepatuhan wajib pajak. hal ini dibuktikan dengan hasil perbandingan nilai koefisen jalur sebesar 0,690 degan nilai t sebesar 12,286. Nilai tersebut lebih besar dari nilai t tabel 1,96. Hal ini menunjukan bahwa Modernisasi Sistem Administrasi Perpajakan dapat membantu wajib pajak dalam meningkatkan kepatuhan pajak. dapat ditarik kesimpulan bahwa keberhasilan yang didapatkan dari implementasi Modernisasi Sistem Administrasi Perpajakan ini merupakan salah satu faktor yang mempengaruhi kepatuhan Wajib Pajak.

Hasil penelitian ini diperkuat penelitian Widya K Sarunan (2016) dan Harrison Mwangi Muturi Dan Nahashon Kiarie (2015) yang menyatakan bahwa implementasi Sistem Administrasi Perpajakan berpengaruh postif terhadap kepatuhan wajib pajak.

\section{Pengaruh Implentasi Sanksi Perpajakan Terhadap Kepatuhan wajib Pajak}

Implementasi Sanksi pajak mempunyai pengaruh yang positif dan signifikan terhadap kepatuhan wajib pajak. hal ini dibuktikan dengan hasil perbandingan nilai koefisen jalur sebesar 0,224 dengan nilai t sebesar 3,456. Nilai tersebut lebih besar dari nilai t tabel 1,96. Hal ini menunjukan bahwa Sanksi Perpajakan dapat membantu wajib pajak dalam meningkatkan kepatuhan pajak. dapat ditarik kesimpulan bahwa keberhasilan yang didapatkan dari implementasi Sanksi Perpajakan ini merupakan salah satu faktor yang mempengaruhi kepatuhan Wajib Pajak.

Hasil penelitian ini diperkuat penelitian Randi Ilhamsyah, Maria G. Wi Endang, Dan Rizky Yudhi Dewantara (2016) dan Arifah, Rita Andini, Dan Kharis Raharjo (2017) yang menyatakan bahwa Sanksi Perpajakan berpengaruh positif dan signifikan terhadap kepatuhan wajib pajak.

\section{KESIMPULAN DAN SARAN \\ Kesimpulan}

Berdasarkan dari data yang telah dipaparkan dan pengujian yang telah dilakukan terhadap permasalahan mengenai Modernisasi Adminitrasi Perpajakan, Sanksi Perpajakan terhadap Kepatuhan Wajib Pajak di Kantor Pelayanan Pajak (KPP) Palmerah Jakarta Barat, maka dapat diambil kesimpulan sebagai berikut:

1. Modernisasi Sistem Administrasi Perpajakan berpengaruh signifikan terhadap Kepatuhan Wajib Pajak Orang Pribadi di KPP palmerah Jakarta Barat. Hal ini dapat dikatakan bahwa Modernisasi Sistem Administrasi Perpajakan berjalan dengan baik sehingga pemahaman Wajib Pajak tentang Modernisasi Sistem Administrasi Perpajakan meningkat dan Kepatuhan Wajib Pajak dalam menjalankan kewajibannya meningkat juga.

2. Penerapan Sanski perpajakan berpengaruh positif dan signifikan terhadap kepatuhan wajib pajak oarang pribadi. selain karena Sanski yang diberikan cukup baik diterima oleh masyarakat dan adanya sosialisasi yang diberikan oleh petugas pajak agar lebih memahami peraturan yang diberikan.

\section{Saran}

Berdasarkan hasil dan analisis serta pembahasan dan kesimpulan yang telah dipaparkan didalam penelitian ini, maka penulis memberikan saran yang akan dijadikan masukan dan bahan pertimbangan bagi pihak - pihak yang berkepentingan yaitu sebagai berikut:

1. Dari hasil penelitian ini, diharapkan KPP Palmerah Jakarta Barat melakukan kinerja yang lebih baik lagi untuk meningkatkan Kualitas Modernisasi Sistem Administrasi 
Perpajakan, Sanksi Pajak yang tegas untuk meningkatkan Kepatuhan wajib Pajak itu sendiri.

2. Akademisi

Diharapkan bagi akademisi yang ingin meneliti kembali penelitian ini, agar dapat memperluas variasi responden. Karena didalam penelitian ini keterbatasan responden hanya dikalangan PNS dan non-PNS (Swasta) saja.

\section{DAFTAR RUJUKAN}

Candra, Ricki, Haris Wibisono dan Mujilan 2013. MODERNISASI SISTEM ADMINISTRASI PERPAJAKAN DAN KEPATUHAN WAJIB PAJAK. Jurnal Riset Manajemen dan Akuntansi. Vol. 1 No. 1, Februari 201.

Daito, A. (2007). Metodologi Penelitian Penyusunan Skripsi. Tesisi/Disertasi., Jakarta., Universitas Budi Luhur.

Direktorat Jendral Pajak "e-spt" diakses dari situs www.pajak.go.id pada 20 februari 2015.

Direktorat Jendral Pajak "penyampaian surat pemberitahuan online (e-filling)" diakses dari situs www.pajak.go.id pada 20 februari 2015.

Direktorat Jendral Pajak. 2012. “Administrasi Perpajakan” diakses dari situs www.reform.depkeu.go.id 13 agustus 2014.

Direktorat Jendral Pajak. 2012. "Mencicipi Modernisasi Perpajakan" diakses dari situs www.pajak.go.id 23 agustus 2014.

Hariwijaya dan Triton. 2011. Pedoman Penulisan Ilmiah Skripsi dan Tesis. Jakarta : Oryza.

Madewing, Irmayanti. 2013. Pengaruh Sistem Modernisasi Administrasi Perpajakan Terhadap Kepatuhan Wajib Pajak. Skripsi. Makasar Universitas Hasanuddin.

Mardiasmo. 2011. Perpajakan Edisi Revisi 2011. Yogyakarta: Andi.

Muljono, Djoko. 2010. Akuntansi pajak lanjutan. Jakarta: salemba empat.

Nasucha, Chaizi 2004, Reformasi Adminstrasi Publik Teori dan Praktik, PT

GramediaWidiasarana Indonesia, Jakarta.

Pandiangan, Liberti. 2008. Modernisasi \& Reformasi Pelayanan Perpajakan Berdasarkan UU Terbaru. Jakarta: PT Elex Media Komputindo.

Rahayu, Sri, Lingga dan Ita Salsallina 2009. Pengaruh Modernisasi Sistem Administrasi Perpajakan Terhadap Kepatuhan Wajib Pajak. Jurnal Akuntansi . Vol.1 No.2 November 2009. 